\title{
Patients' beliefs about generic medicines in Malaysia
}

\author{
Zhi Y. WONG, Mohamed A. HASSALI, Alian A. ALRASHEEDY, Fahad SALEEM, \\ Abdul H. YAHAYA, Hisham ALJADHEY. \\ Received (first version): 18-Jun-2014 Accepted: 24-Nov-2014
}

\begin{abstract}
${ }^{*}$
Background: Acceptance of generic medicines by patients is an essential factor given that they are the end users of these medicines. In fact, adequate knowledge and positive perceptions are prerequisite to patients' acceptance and use of generic medicines.

Objective: To assess the current belief and views of patients about generic medicines in Malaysia.

Method: This was a self-administered questionnairebased study. The study was conducted with patients visiting outpatient pharmacy department at a tertiary care hospital in Malaysia. The Malaysian version of Generic Medicines Scale (GMS) was used. The GMS consists of two subscales: efficacy and similarity of generic medicines to original brand medicines. The efficacy subscale consists of 10 items while the similarity subscale consists of 6 items. The responses to the items were framed as a fivepoint Likert scale $(1=$ strongly disagree to $5=$ strongly agree).

Results: A total of 202 out of 300 patients participated in the study, giving a response rate of $67.3 \%$. In this study, only $49 \%$ of them $(n=99)$ knew the term 'generic medicine'. Moreover, only $53.5 \%$ of the respondents $(n=108)$ believed that the efficacy of generic medicines was the same as original brand medicines. In terms of quality, only $44 \%$ of the respondents $(n=89)$ disagreed that generic medicines were of a lower quality. About one third $(n=65,32.2 \%)$ believed that generic medicines were cheaper because they were less efficacious. In terms of side effects, $44.5 \%$ of the respondents $(n=90)$ believed that generic medicines had the same side effect profile as original brand medicines.

Conclusions: The study finding showed that almost half of the respondents had negative belief in generic medicines. Similarly, many patients were not aware of the similarities and differences between generic and original brand medicines. Therefore, there is a need to provide patients with adequate information about generic medicines.
\end{abstract}

Keywords: Drugs, Generic; Health Knowledge, Attitudes, Practice; Patient Education as Topic; Therapeutic Equivalency; Malaysia

Zhi Yen WONG. Pharmacy Department, Hospital Teluk Intan. Perak (Malaysia). wongzy88@gmail.com Mohamed Azmi HASSALI. Discipline of Social and Administrative Pharmacy, School of Pharmaceutical Sciences, Universiti Sains Malaysia. Penang (Malaysia). azmihassali@gmail.com

Alian A. ALRASHEEDY. Discipline of Social and Administrative Pharmacy, School of Pharmaceutical Sciences, Universiti Sains Malaysia. Penang (Malaysia). alian-a@hotmail.com

Fahad SALEEM. Discipline of Social and Administrative Pharmacy, School of Pharmaceutical Sciences, Universiti Sains Malaysia. Penang (Malaysia). fahaduob@gmail.com Abdul Haniff Mohamad YAHAYA. Pharmacy Department, Hospital Teluk Intan. Perak (Malaysia). dulha5@yahoo.com

Hisham ALJADHEY. College of Pharmacy, King Saud University. Riyadh (Saudi Arabia). haljadhey@ksu.edu.sa

\section{INTRODUCTION}

Healthcare expenditure was escalating throughout the years. ${ }^{1,2}$ An increase in the elderly population, high prevalence of chronic diseases, high utilization of healthcare service were the main factors contributing for escalating healthcare cost. ${ }^{3}$ Similarly, pharmaceutical expenditure - one of the fast growing component of healthcare expenditure is steadily increasing. ${ }^{4}$ Meanwhile, utilization of generic medicines is identified as one of the effective mechanisms to curb the escalating pharmaceutical cost. ${ }^{5-8}$ In fact, in many countries including Malaysia, generic medicines are approximately $20-90 \%$ cheaper than brand innovator products. ${ }^{9-12}$ Therefore, in recent years, various policies, initiatives, and strategies were formulated by governments and policy makers to encourage the use of generic medicines as an integral part of the health care system., ${ }^{43-15}$ In Malaysia, generic medicines policy (GMP), which is part of the National Medicines Policy, was formulated in year 2006 to encourage the utilization of generic medicines among different healthcare stakeholders. $^{16,17}$ Various strategies were formulated in GMP to encourage the utilization of generic medicines: (1) Prescribing by using generic name or International Non-proprieatary Name (INN) shall be practiced at all levels, (2) promoting the use of generic names or INN in procurement of medicines, (3) priority shall be given to locally manufactured medicines in terms of pharmaceutical procurement, (4) using the generic names or INN with or without the trade names in labelling for dispensed medicines should be encouraged, (5) establishment or formation of formulary of interchangeable medicines, (6) for all interchangeable medicines, generic substitution shall be allowed and encouraged. Amidst them all, the acceptance of generic medicines by patients is an essential factor given that patients are the end users of these medicines. ${ }^{18,19}$ In fact, adequate knowledge, and positive perceptions are prerequisite to acceptance and use of generic medicines by patients ${ }^{18,19}$ because insufficient information and lack of understanding of generic medicines is one of the main barriers to the wider use of these medicines. ${ }^{19-22}$

In literature, there are two studies conducted in Malaysia regarding consumers' perceptions of generic medicines. ${ }^{23,24}$ However, these studies were conducted before the implementation of generic medicine policy. ${ }^{25}$ Moreover, people's views and knowledge might have changed especially in the recent years because several educational activities and nationwide awareness programs have been 
conducted to educate patients about generic medicines. $^{25,26}$ Therefore, the objective of this study was to assess the current belief and views of patients about generic medicines in Malaysia.

\section{METHODS}

\section{Design and Setting}

A cross sectional study design was adopted to conduct this study. The study was conducted in a tertiary care hospital in Perak, Malaysia. The hospital has 24 wards and 548 beds. ${ }^{27}$

\section{Sampling and Sample Size}

Patients with age older than 18 years old and literate (i.e. able to speak, read and write) with Bahasa Malaysia (National Language of Malaysia), were enrolled in the study. Patient with severe health problems of cognitive impairment and caregivers are excluded from the study. Using Cochran equation with $80 \%$ confidence level and $5 \%$ precision and degree of variability of 0.3 , the minimum required sample size is 138 patients. ${ }^{28}$ Then, to take into account non-response rate, the sample size was increased to 300 . The convenience sampling was the sampling strategy used in this study.

\section{Instrument}

Generic Medicines Scale (GMS) was developed by Figueiras et al. (2009) to assess medicine consumers/patients beliefs about generic medicines. ${ }^{29}$ The GMS consists of two subscales: efficacy and similarity of generic medicines to original brand medicines. The efficacy subscale consists of 10 items while the similarity subscale consists of 6 items. The responses to the items were framed as a five-point Likert scale (1=strongly disagree, 2=disagree, 3=neutral, 4=agree and $5=$ strongly agree). The GMS was translated to Bahasa Malaysia. The Malaysian version of the GMS was valid and reliable to be used in Malaysian setting (online supplementary material). The process of translation and validation was published by our research group elsewhere. ${ }^{30}$

\section{Data collection}

The questionnaire was self-administered in nature. The questionnaires were distributed to patients during their waiting time to get the medications in outpatient pharmacy department. Along with the questionnaire, a cover letter explaining study background, purpose, procedure of the study and a brief explanatory statement on the definition of generic and original brand medicine was given to the participants. The data collection period was between $1^{\text {st }}$ October 2013 and $31^{\text {st }}$ October 2013.

\section{Data analysis}

Descriptive statistics were used to describe the demographic characteristics. Normality of data was tested using Kolmogorov-Smirnov test. MannWhitney and Kruskal-Wallis test were used to detect whether there are differences in participants' responses in terms of their demographic characteristics. All statistical tests were conducted at a priori significance level of $p<0.05$. However, when using Mann-Whitney for post hoc follow-up tests for the Kruskal-Wallis, to control and prevent inflation of type I errors, a Bonferroni correction to the alpha values was done..$^{31,32}$ Thus, depending on the number of comparison groups, the significance level was adjusted when running the post hoc analysis (e.g. for three comparisons, the $P$ value was divided by three $(0.05 / 3)$ and corrected to be $0.0167)$. The data analysis was performed using the statistical package for social sciences (SPSS) version 16 for Windows.

\section{RESULTS}

\section{Demographic characteristics}

A total of 202 out of 300 patients participated in the study, giving a response rate of $67.3 \%$. Table 1 shows that majority of the respondents were female $(55.4 \%)$ and Malay (64.0\%). About fifty-three percent of the respondents were above 40 years old. Only $16 \%$ of the respondents had a university level of education or higher. About $20 \%$ of the respondents had monthly income above MYR3000 $(1 \mathrm{USD}=$ MYR3.33)

\begin{tabular}{|c|c|}
\hline Demographic Characteristics & $\begin{array}{c}\text { Total sample } \\
\mathrm{N}=202\end{array}$ \\
\hline $\begin{array}{r}\text { Male } \\
\text { Female } \\
\text { Missing data }\end{array}$ & $\begin{array}{c}86(42.6) \\
112(55.4) \\
4(2.0)\end{array}$ \\
\hline $\begin{array}{r}\text { Malay } \\
\text { Chinese } \\
\text { Indian } \\
\text { Others } \\
\text { Missing data }\end{array}$ & $\begin{array}{c}130(64.0) \\
30(14.9) \\
37(18.3) \\
2(1.0) \\
3(1.5) \\
\end{array}$ \\
\hline $\begin{array}{r}\text { Below } 30 \\
30-40 \\
41-50 \\
51-60 \\
61 \text { and above } \\
\text { Missing data }\end{array}$ & $\begin{array}{c}53(26.2) \\
36(17.8) \\
47(23.3) \\
33(16.3) \\
28(13.9) \\
5(2.5)\end{array}$ \\
\hline $\begin{array}{r}\text { Education level } \\
\text { Primary education } \\
\text { Intermediate education } \\
\text { Secondary education } \\
\text { A-level/Matriculation/pre-university } \\
\text { Diploma } \\
\text { Undergraduate degree } \\
\text { Postgraduate degree } \\
\text { Missing data }\end{array}$ & $\begin{array}{c}10(5.0) \\
23(11.4) \\
78(38.6) \\
11(5.4) \\
36(17.8) \\
29(14.4) \\
4(2.0) \\
11(5.4 \%)\end{array}$ \\
\hline $\begin{array}{rr}\text { Monthly income }\left(\mathrm{RM}^{*}\right) & <\mathrm{RM} 1000 \\
\mathrm{RM} 1000-\mathrm{RM} 2000 \\
\mathrm{RM} 2001-\mathrm{RM} 3000 \\
\mathrm{RM} 3001-\mathrm{RM} 4000 \\
>\mathrm{RM} 4000 \\
\text { Missing data }\end{array}$ & $\begin{array}{c}43(21.3) \\
48(23.8) \\
24(11.9) \\
19(9.4) \\
20(9.9) \\
48(23.8) \\
\end{array}$ \\
\hline $\begin{array}{r}\text { Ask doctor about medications } \\
\text { Yes } \\
\text { No } \\
\text { Missing Data }\end{array}$ & $\begin{array}{c}143(70.8) \\
55(27.2) \\
4(2.0)\end{array}$ \\
\hline $\begin{array}{r}\text { Know about generic medicine } \\
\text { Yes } \\
\text { No } \\
\text { Missing Data }\end{array}$ & $\begin{array}{c}99(49.0) \\
97(48.0) \\
6(3.0)\end{array}$ \\
\hline
\end{tabular}




\section{Table 2. Patients' beliefs about the efficacy of generic medicines \\ 1. The efficacy of generic medicines is the same as brand medicines. \\ 2. Generic medicines take longer time to be efficacious. \\ 3. Generic medicines are good for less serious diseases. \\ 4. Treatments with generic medicines take longer. \\ 5. Generic medicines are made with lower quality substances. \\ 6. Generic antibiotics are less efficacious than brand antibiotics. \\ 7. Generic medicines have a better quality control than brand medicines. \\ 8. Generic medicines are cheaper because they are less efficacious. \\ 9. Generic medicines have the same effect than brand ones. \\ 10. Generic medicines are used for the same illnesses. \\ Source of drug information and knowledge about the term generic medicine \\ Most of the respondents surveyed ( $n=143,70.8 \%)$ asked doctors about their medicines. However, only $49 \%$ of them $(n=99)$ knew the term 'generic medicine'. \\ Beliefs about the efficacy of generic medicines \\ In this study, only $53.5 \%$ of the respondents $(n=108)$ believed that the efficacy of generic medicines was the same as original brand medicines. Moreover, $41.5 \% \quad(n=84)$ of the respondents believed that generic medicines took longer to be effective. Therefore, most of the respondents $(n=133,65.8 \%)$ believed that generic medicines were good for less serious diseases. In terms of quality, only $44 \%$ of the respondents $(n=89)$ disagreed that generic medicines were of lower quality. About one third $(n=65,32.2 \%)$ believed that generic medicines were cheaper because they were less efficacious. Table 2 shows the responses of the patients on the statements regarding their beliefs about the efficacy of generic medicines.}

\section{Beliefs about the similarity of generic medicines}

In this study, $50 \% \quad(n=101)$ of the respondents believed that generic medicines have a similar taste as original brand medicines. Similarly, most of

\begin{tabular}{|c|c|c|c|c|c|}
\hline \multicolumn{7}{|c|}{$\mathrm{n}(\%)$} \\
\hline $\begin{array}{c}\text { Strongly } \\
\text { disagree }\end{array}$ & Disagree & Neutral & Agree & $\begin{array}{c}\text { Strongly } \\
\text { agree }\end{array}$ & Missing \\
\hline 6 & $40(19.8)$ & 48 & 87 & 21 & 0 \\
$(3.0)$ & $(23.8)$ & $(43.1)$ & $(10.4)$ & $(0.0)$ \\
\hline 4 & 47 & 65 & 73 & 11 & 2 \\
$(2.0)$ & $(23.3)$ & $(32.2)$ & $(36.1)$ & $(5.4)$ & $(1.0)$ \\
\hline 3 & 20 & 44 & 116 & 17 & 2 \\
$(1.5)$ & $(9.9)$ & $(21.8)$ & $(57.4)$ & $(8.4)$ & $(1.0)$ \\
\hline 8 & 54 & 63 & 61 & 12 & 4 \\
$(4.0)$ & $(26.7)$ & $(31.2)$ & $(30.2)$ & $(5.9)$ & $(2.0)$ \\
\hline 15 & 74 & 61 & 37 & 10 & 5 \\
$(7.4)$ & $(36.6)$ & $(30.2)$ & $(18.3)$ & $(5.0)$ & $(2.5)$ \\
\hline 8 & 50 & 57 & 64 & 20 & 3 \\
$(4.0)$ & $(24.8)$ & $(28.2)$ & $(31.7)$ & $(9.9)$ & $(1.5)$ \\
\hline 7 & 43 & 71 & 63 & 17 & 1 \\
$(3.5)$ & $(21.3)$ & $(35.1)$ & $(31.2)$ & $(8.4)$ & $(0.5)$ \\
\hline 10 & 74 & 49 & 49 & 16 & 4 \\
$(5.0)$ & $(36.6)$ & $(24.3)$ & $(24.3)$ & $(7.9)$ & $(2.0)$ \\
\hline 3 & 45 & 55 & 88 & 10 & 1 \\
$(1.5)$ & $(22.3)$ & $(27.2)$ & $(43.6)$ & $(5.0)$ & $(0.5)$ \\
\hline 2 & 25 & 55 & 101 & 18 & 1 \\
$(1.0)$ & $(12.4)$ & $(27.2)$ & $(50.0)$ & $(8.9)$ & $(0.5)$ \\
\hline \multicolumn{7}{|c|}{} & & & & \\
\end{tabular}

respondents $(n=139,68.8 \%)$ knew that the packaging of generic medicines was different from original brand medicines. Most of them $(n=133$, $65.8 \%$ ) also believed that the indication of generic medicines is the same as original brand counterparts. In terms of side effects, $44.5 \%$ of the respondents $(n=90)$ believed that generic medicines have the same side effect profile as original brand medicines. Table 3 shows the responses of the patients on various statements regarding their beliefs about the similarity of generic medicines.

\section{Comparison between demographic characteristics}

The participants' responses to statements were assessed to determine whether there are significant differences in terms of their demographic data. The comparison analysis is presented in Table 4.

There were significant differences between the respondents in terms of their race and their responses to the statement about the efficacy of generic medicines is the same as brand medicines $(p=0.001)$. The follow-up analysis showed that Malay (Md=4 (IQR=3-4)) had a statistically significant higher level of agreement with the statement compared to the Chinese $(\mathrm{Md}=3(\mathrm{IQR}=2$ 4)) $(p=0.001)$. However, no statistically significant differences were found among other ethnic groups.

\begin{tabular}{|c|c|c|c|c|c|c|}
\hline \multirow[b]{2}{*}{ Items in questionnaire } & \multicolumn{6}{|c|}{$\mathrm{n}(\%)$} \\
\hline & $\begin{array}{l}\text { Strongly } \\
\text { disagree }\end{array}$ & Disagree & Neutral & Agree & $\begin{array}{l}\text { Strongly } \\
\text { agree }\end{array}$ & Missing \\
\hline $\begin{array}{l}\text { 12. Generic medicines have a similar taste as brand } \\
\text { medicines. }\end{array}$ & $\begin{array}{c}7 \\
(3.5) \\
\end{array}$ & $\begin{array}{c}32 \\
(15.8) \\
\end{array}$ & $\begin{array}{c}59 \\
(29.2) \\
\end{array}$ & $\begin{array}{c}88 \\
(43.6) \\
\end{array}$ & $\begin{array}{c}13 \\
(6.4) \\
\end{array}$ & $\begin{array}{c}3 \\
(1.5) \\
\end{array}$ \\
\hline $\begin{array}{l}\text { 14. Generic medicines have a different box from brand } \\
\text { medicines. }\end{array}$ & $\begin{array}{c}3 \\
(1.5) \\
\end{array}$ & $\begin{array}{c}23 \\
(11.4) \\
\end{array}$ & $\begin{array}{c}37 \\
(18.3) \\
\end{array}$ & $\begin{array}{c}116 \\
(57.4) \\
\end{array}$ & $\begin{array}{c}23 \\
(11.4)\end{array}$ & $\begin{array}{c}0 \\
(0.0) \\
\end{array}$ \\
\hline $\begin{array}{l}\text { 15. The use of generic medicines is similar to brand } \\
\text { ones. }\end{array}$ & $\begin{array}{c}2 \\
(1.0)\end{array}$ & $\begin{array}{c}20 \\
(9.9)\end{array}$ & $\begin{array}{c}46 \\
(22.8)\end{array}$ & $\begin{array}{c}113 \\
(55.9) \\
\end{array}$ & $\begin{array}{c}20 \\
(9.9) \\
\end{array}$ & $\begin{array}{c}1 \\
(0.5)\end{array}$ \\
\hline $\begin{array}{l}\text { 16. Generic medicines are exactly the same as brand } \\
\text { medicines. }\end{array}$ & $\begin{array}{c}6 \\
(3.0)\end{array}$ & $\begin{array}{c}38 \\
(18.8)\end{array}$ & $\begin{array}{c}57 \\
(28.2)\end{array}$ & $\begin{array}{c}80 \\
(39.6)\end{array}$ & $\begin{array}{c}20 \\
(9.9)\end{array}$ & $\begin{array}{c}1 \\
(0.5)\end{array}$ \\
\hline
\end{tabular}




\begin{tabular}{|c|c|c|c|c|c|}
\hline Items in questionnaire & Gender* & Race $^{\star *}$ & Age $^{* *}$ & $\begin{array}{c}\text { Education } \\
\text { level }{ }^{* *}\end{array}$ & $\begin{array}{l}\text { Monthly } \\
\text { income }\end{array}$ \\
\hline $\begin{array}{l}\text { 1. The efficacy of generic medicines is the same as brand } \\
\text { medicines. }\end{array}$ & 0.425 & $0.001^{\mathrm{a}}$ & 0.066 & 0.024 & 0.918 \\
\hline 2. Generic medicines take longer time to be efficacious & 0.171 & 0.195 & 0.629 & 0.506 & 0.762 \\
\hline 3. Generic medicines are good for less serious diseases. & 0.055 & $0.003^{\mathrm{a}}$ & 0.850 & 0.216 & 0.069 \\
\hline 4. Treatments with generic medicines take longer. & 0.715 & 0.659 & 0.137 & 0.735 & 0.965 \\
\hline 5. Generic medicines are made with lower quality substances. & 0.052 & 0.385 & 0.729 & 0.085 & 0.947 \\
\hline 6. Generic antibiotics are less efficacious than brand antibiotics. & 0.593 & 0.717 & 0.997 & 0.284 & 0.709 \\
\hline $\begin{array}{l}\text { 7. Generic medicines have a better quality control than brand } \\
\text { medicines. }\end{array}$ & 0.002 & 0.111 & 0.674 & $0.011^{\mathrm{a}}$ & $0.003^{\mathrm{a}}$ \\
\hline $\begin{array}{l}\text { 8. Generic medicines are cheaper because they are less } \\
\text { efficacious. }\end{array}$ & 0.200 & 0.332 & 0.870 & 0.553 & 0.782 \\
\hline 9. Generic medicines have the same effect than brand ones. & 0.585 & 0.089 & 0.176 & 0.760 & 0.237 \\
\hline 10. Generic medicines are used for the same illnesses. & 0.010 & 0.854 & 0.091 & 0.038 & 0.592 \\
\hline 11. Generic tablets are the same as brand ones. & 0.896 & 0.099 & $0.019^{\mathrm{a}}$ & 0.484 & 0.231 \\
\hline 12. Generic medicines have a similar taste as brand medicines. & 0.789 & 0.030 & $0.016^{\mathrm{a}}$ & 0.097 & 0.968 \\
\hline $\begin{array}{l}\text { 13. Generic medicines have the same side effects as brand } \\
\text { medicines. }\end{array}$ & 0.652 & 0.851 & 0.326 & 0.327 & 0.833 \\
\hline 14. Generic medicines have a different box from brand medicines. & 0.780 & 0.816 & 0.128 & 0.918 & 0.104 \\
\hline 15. The use of generic medicines is similar to brand ones. & 0.955 & 0.617 & 0.152 & 0.092 & 0.217 \\
\hline 16. Generic medicines are exactly the same as brand medicines. & 0.361 & $0.006^{\mathrm{a}}$ & 0.035 & 0.283 & 0.420 \\
\hline
\end{tabular}

There were significant differences between the respondents in terms of their race and their responses to the statement about 'generic medicines are good for less serious diseases' $(p=0.003)$. The follow-up analysis showed that Malay (Md=4 (IQR=4-4)) had a statistically significant higher level of agreement with the statement compared to the Chinese (Md=3 (IQR=24)) $(p=0.001)$. However, no statistically significant differences were found among other ethnic groups.

There were significant differences between the respondents in terms of gender and their responses to the statement about 'Generic medicines have a better quality control than brand medicines' with male participants $(\mathrm{Md}=3 \quad(\mathrm{IQR}=3-4))$ recorded a statistically significant higher level of agreement than female participants (Md=3 (IQR=2-4)) $(p=0.002)$. Moreover, there were significant differences between the respondents in terms of education level and their responses to this statement $(p=0.011)$. The follow-up analysis showed that respondents with a degree $(\mathrm{Md}=3$ $(I Q R=2-3))$ recorded a statistically significant lower level of agreement than participants with primary education (Md=4 (IQR=3-4.25) $\quad(p=0.001)$ and intermediate education $((\mathrm{Md}=4 \quad(\mathrm{IQR}=3-4))$ $(p=0.002)$. However, no statistically significant differences were found among other education levels. Moreover, there were significant differences between the respondents in terms of income level and their responses to this statement $(p=0.003)$. The follow-up analysis showed that respondents with monthly income MYR3000 to MYR4000 (Md=3 $(I Q R=2-3))$ recorded a statistically significant lower level of agreement than participants with month income less than MYR1000 (Md=4 (IQR=3-4)) $(p=0.001)$. However, no statistically significant differences were found among other income levels.

There were significant differences between the respondents in terms of gender and their responses to the statement about 'Generic medicines are used for the same illnesses' with male participants tend to record a higher level of agreement than female participants (Mean ranks are 109.93 and 90.53 for male and female respectively, $p=0.010$ ).

There were significant differences between the respondents in terms of their age and their responses to the statement about 'Generic tablets are the same as brand ones' $(p=0.019)$. The followup analysis showed that respondents in the age group 41-50 years old ( $M d=4(I Q R=3-4))$ recorded a statistically significant higher level of agreement than participants in the age group 51-60 years $(\mathrm{Md}=2 \quad(\mathrm{IQR}=2-3.75)) \quad(\mathrm{p}=0.004)$. However, no statistically significant differences were found among other age groups.

There were significant differences between the respondents in terms of their age and their responses to the statement about 'Generic medicines have a similar taste as brand medicines' $(p=0.016)$. The follow-up analysis showed that respondents in the age group 61-70 years old $(\mathrm{Md}=4(\mathrm{IQR}=3-4))$ recorded a statistically significant higher level of agreement than participants with age below 30 years $(\mathrm{Md}=3 \quad(\mathrm{IQR}=3-4)) \quad(p=0.002)$. However, no statistically significant differences were found among other age groups.

There were significant differences between the respondents in terms of their race and their responses to the statement 'Generic medicines are exactly the same as brand medicines' $(p=0.006)$. The follow-up analysis showed that Malay $(\mathrm{Md}=4$ $(I Q R=3-4))$ had a statistically significant higher level of agreement with the statement compared to the Chinese $(M d=2(I Q R=2-4))(p<0.001)$. However, no statistically significant differences were found among other ethnic groups.

\section{DISCUSSION}

Malaysia's healthcare system consists of two sectors, namely public and private sector. In public sector, the healthcare services is heavily subsidized by the government and the patients only required to 
pay minimal co-payment (i.e citizens only have to pay MYR 1 for one visit to outpatient department and MYR 5 for visiting a specialists' clinic) while private sectors are funded mainly by patients' out-of pocket payment. ${ }^{33}$ Therefore, promotion of generic medicines can lead to substantial saving to the government and patients. ${ }^{34}$ Hence, patients' knowledge and acceptance are prerequisite for wide use of generic medicines. In this regard, the present study reported that $49 \%$ of the respondents knew the term "generic medicine". This is better than the findings of previous studies conducted in Malaysia (Kuala Lumpur and Selangor, Penang) and some countries such as Jamaica $(32.5 \%, 28.3 \%$ and $36.4 \%$, respectively). ${ }^{23,24,35}$ However, it is still lower compared to other countries such as Portugal, the UK, Japan and New Zealand (100\%, 70\%, 68.4\% and $51.6 \%$ respectively). ${ }^{21,36,37}$ Therefore, communication between healthcare professionals and patients about generic medicines is one of the most important factors associated with use of generic medicines. ${ }^{38}$ In this study, most of the surveyed patients $(70.8 \%)$ mentioned that they communicated with their doctors about their medicines. In Malaysia, there is currently no dispensing separation. Medical practitioners still follow a traditional 'dispensing doctors' system in which medical practitioners still dispenses medications as part of their professional practice. ${ }^{39}$ This is because the 1952 Poison Act in Malaysia granted the right for registered medical practitioners to prescribe and dispense medicines in their clinics. $^{40}$ Hence, the influence of medical practitioners on patients' selection of either generic or original brand medicines cannot be neglected. ${ }^{41-}$

44 In fact, medical practitioners do not only persuade patients accept to generic medicines, but also to make them confident and feel more comfortable about using these medicines. Therefore, medical practitioners need to actively inform their patients about generic medicines. ${ }^{19}$

In this study, $53.5 \%$ believed that the efficacy of generic medicines is the same as brand original medicines. This might be due to patients' experience with using generic medicines in public hospitals since most of the medicines dispensed in public hospitals and clinics are generic medicines. In fact, previous experience with generic medicines was significantly associated with the increased acceptance of generic medicines. ${ }^{21,37,41,45,46}$ However, a sizeable proportion of participants in this study still have misconception about the efficacy of generic medicines. In fact, in literature, misconceptions and negative perceptions is still widely reported among a sizeable proportion of patients and medicine consumers in many countries. ${ }^{20,21,24,47-52}$

Moreover, majority of the respondents $(65.8 \%)$ believed that generic medicines were good for less serious diseases. This implies that patients still do not have full confidence to use generic medicines for serious or life threatening diseases. In fact, the seriousness of the medical case/disease is an important factor, and the more serious or risky the patient perceives the condition to be, the less likely they are to use a generic medicine. ${ }^{22,53,54}$ About one third of respondents $(32.2 \%)$ were sceptical about the efficacy of generic medicines because they were cheaper. This finding was consistent with a study conducted in Germany. ${ }^{41}$ Therefore, this misconception or myth that lower price equates to lower quality, need to be addressed and corrected. $^{19,55}$

In terms of quality, only $44 \%$ of the respondents $(n=89)$ disagreed that generic medicines were of lower quality. Therefore, it is important to correct this misconception. In fact, in Malaysia, generic manufacturers have to follow Good Manufacturing Practice Requirement, guidelines for pharmaceutical development, product testing (i.e. both compendial and non compendial testing) and the content of Common Technical Document for regulatory submission which are adopted from competent regulatory agencies in the EU, the United States as well as the International Conference on Harmonisation (ICH). ${ }^{56,57}$ Moreover, before registration, generic medicines must undergo a rigorous registration process to ensure the quality, safety, efficacy and bioequivalence. Therefore, it is important to empower patients with information about regulatory approval and registration system for medicines in their country. ${ }^{25}$

Regarding the similarity of generic medicines, most of respondents knew that the similarity between generic and original brand medicines. Similar to our findings, majority of the participants from the UK and Portugal reported that they are aware of the availability of different brands (ie, versions) of the "same medicine". ${ }^{36,46}$ However, in some other countries such as Bulgaria, Iraq, Norway and Japan, patients lack of knowledge about the similarity and difference between generic and original brand medicines. ${ }^{37,52,58,59}$

Few demographic characteristics were found to have significant effects on patients' beliefs about generic medicines. Respondents with higher levels of education and higher income levels expressed better understanding of quality control of generic medicines. Previous studies have confirmed that patients with higher income levels ${ }^{42}$ and higher levels of education ${ }^{21,36,41,42,46}$ tended to have positive views about generic medicines. The respondents aged between 61-70 years expressed stronger belief that generic medicines have a similar taste as original brand medicines than those aged less than 30 years. A possible reason is that most medicines consumed by the elderly are in solid dosage forms (i.e., different tablets taste similar).

Several recommendations can be made based on the study findings. First, there is a need for educational interventions to provide the patients with adequate knowledge about generic medicines. This can be done by education from healthcare professionals (i.e. medical practitioners and pharmacists). In fact, direct education and advice from healthcare professionals are one of the most effective strategies. ${ }^{20,58}$ Moreover, current awareness programmes need to be continued and expanded to increase the level of patients' awareness. It is important to have a comprehensive and well-designed promotion programme that 
address, from various perspectives, all aspects related to generic medicines including their approval and registration requirements, physical characteristics, quality, safety and efficacy. ${ }^{4}$ However, it should be noted that poorly managed programmes are a barrier to implementation of generic medicine policy. ${ }^{55}$ Moreover, less comprehensive educational campaigns may not achieve the goal and short programmes have minimal impact. 37,60

As there is currently paucity of evidence based data regarding the ideal content and structure of patient educational programmes on generic medicines, it is important that future studies identify the most effective educational interventions. ${ }^{19}$

The study had some limitations. First, convenience sampling was the adopted sampling strategy. Moreover, this study was conducted only in one state. Hence, the findings might not be possible to be generalized to the whole country. However, it can provide useful data for health policy makers to further improve the use of generic medicines by considering the patients' perspectives.

\section{CONCLUSIONS}

The study finding showed that only half of the participants were familiar with the term "generic medicine". Moreover, almost half of the participants had negative belief in generic medicines. Similarly, many patients were not aware of the similarities and differences between generic and original brand medicines. Therefore, there is a need to provide the patients with adequate information about generic medicines including their about quality, safety and efficacy.

\section{ACKNOWLEDGEMENTS}

The authors would like to thank the Director of Health Malaysia for permission to publish this paper. The authors wish to thank all the participants for their participation in the study

\section{CREENCIAS DE LOS PACIENTES SOBRE LOS MEDICAMENTOS GENÉRICOS EN MALASIA}

\section{RESUMEN}

Antecedentes: La aceptación de los genéricos por los pacientes es un factor esencial dado que son los utilizadores finales de estos medicamentos. De hecho, el conocimiento adecuado y las percepciones positivas son requisitos para la aceptación y el uso de genéricos por los pacientes

Objetivo: Evaluar las creencias y la visión actuales de los pacientes sobre medicamentos genéricos en Malasia. Método: Este fue un estudio basado en un cuestionario auto-administrado. El estudio se realizó con pacientes que visitaron un departamento de farmacia ambulatoria de un hospital terciario en Malasia. Se usó la versión malaya del Generic Medicines Scale (GMS). El GMS consiste en dos escalas: eficacia y semejanza del genérico con el original de marca. La sub-escala de eficacia consiste en 10 ítems, mientras que la de semejanza consiste en 6 ítems. Las respuestas de los ítems se estipularon en una escala de Likert de 5 puntos: ( $1=$ desacuerdo fuerte a $5=$ acuerdo fuerte $)$.

Resultados: Un total de 202 de los 300 pacientes participaron en el estudio, lo que da una tasa de respuesta del 67,3\%. En este estudio, solo el 49\% de ellos ( $n=99)$ conocían el término 'medicamento genérico'. Sólo el $53,5 \%$ de los respondentes $(\mathrm{n}=108)$ creían que la eficacia de los genéricos era la misma que la de los originales de marca. En términos de calidad, solo el $44 \%$ de los respondentes $(n=89)$ estaba en desacuerdo que los genéricos eran de menor calidad. Cerca de un tercio $(\mathrm{n}=65,32,2 \%)$ creía que los genéricos eran más baratos porque eran menos eficaces. En términos de efectos adversos, el $44,5 \%$ de los respondentes $(n=90)$ creía que los genéricos tenían el mismo perfil de efectos adversos que los medicamentos de marca.

Conclusiones: Los hallazgos del estudio demostraron que casi la mitad de los respondentes tenían creencias negativas sobre los genéricos. Del mismo modo, muchos pacientes no conocían las semejanzas y similitudes de los genéricos y los de marca. Por tanto, se necesita proporcionar a los pacientes información adecuada sobre medicamentos genéricos.

Palabras clave: Medicamentos Genéricos; Conocimientos, Actitudes y Práctica en Salud; Educación del Paciente como Asunto; Equivalencia Terapéutica; Malasia

\section{CONFLICT OF INTEREST}

None declared.

\section{References}

1. Borger C, Smith S, Truffer C, Keehan S, Sisko A, Poisal J, Clemens MK. Health spending projections through 2015: changes on the horizon. Health Aff (Millwood). 2006;25(2):w61-w73.

2. Steinwachs DM. Pharmacy benefit plans and prescription drug spending. JAMA. 2002;288(14):1773-1774.

3. Malaysian-German Chamber of Commerce and Industry. "Market Watch 2012" The healthcare sector in Malaysia. 2011. Available from:

http://www.malaysia.ahk.de/fileadmin/ahk malaysia/Market reports/The Healthcare Sector in Malaysia.pdf (accessed 24th April, 2014)

4. Hassali MA, Alrasheedy AA, McLachlan A, Nguyen TA, Al-Tamimi SK, Ibrahim MIM, Aljadhey H. The experiences of implementing generic medicines policy in eight countries: A review and recommendations for a successful promotion of generic medicines use. Saudi Pharm J. 2014. (In press). doi:10.1016/j.jsps.2013.12.017

5. King DR, Kanavos P. Encouraging the use of generic medicines: implications for transition economies. Croat Med J. 2002;43(4):462-469.

6. Kanavos P. Do generics offer significant savings to the UK National Health Service? Curr Med Res Opin 2007;23(1):105-116. 
7. Karim SA, Pillai G, Ziqubu-Page T, Cassimjee M, Morar M. Potential savings from generic prescribing and generic substitution in South Africa. Health Policy Plan. 1996;11(2):198-205.

8. Haas JS, Phillips KA, Gerstenberger EP, Seger AC. Potential savings from substituting generic drugs for brand-name drugs: medical expenditure panel survey, 1997-2000. Ann Intern Med. 2005;142(11):891-897.

9. Shafie AA, Hassali MA. Price comparison between innovator and generic medicines sold by community pharmacies in the state of Penang, Malaysia. J Generic Med. 2008;6(1):35-42.

10. Martin Y. SCRIP's Complete Guide to the World Generic Drugs Market. Richmond, UK: PJB; 1999.

11. European Generic Medicines Association. EGA fact sheet on generic medicines: Frequently Asked Questions (FAQs). Available from: http://www.egagenerics.com/images/factsheet/EGA factsheet 06.pdf (accessed 23rd June 23, 2013).

12. Simoens S, Coaster SD. Sustaining generic medicines markets in Europe. Research Centre for Pharmaceutical Care and Pharmaco-economics, Katholieke Universiteit Leuven. 2006. Available from: http://212.85.101.126/images/publikacje/7 pl.pdf (accessed 30th January, 2014).

13. Godman B, Malmström R, Bennie M, Sakshaug S, Burkhardt T, Campbell S, Garuoliene K, Schwabe U, Vončina L, Gustafsson LL. Prescribing restrictions-a necessary strategy among some European countries to enhance future prescribing efficiency? Rev Health Care. 2011;3(1):5-16.

14. Godman B, Shrank W, Wettermark B, Andersen M, Bishop I, Burkhardt T, Garuolienè K, Kalaba M, Laius O, Joppi R. Use of generics - a critical cost containment measure for all healthcare professionals in Europe? Pharmaceuticals. 2010;3(8):2470-2494. doi:10.3390/ph3082470

15. Godman B, Wettermark B, Bishop I, Burkhardt T, Fürst J, Garuoliene K, Laius L, Martikainen J, Semet C, Teixeira I. European payer initiatives to reduce prescribing costs through use of generics. GaBI J. 2012;1(1):22-27.

16. Ministry of Health Malaysia. Malaysian National Medicines Policy. 2007. Available from: http://www.pharmacy.gov.my/aeimages//File/MNMP DUNAS.pdf (accessed 24th April, 2014).

17. Ministry of Health Malaysia. Malaysian National Medicines Policy. 2012. Available from: http://www.pharmacy.gov.my/v2/sites/default/files/document-upload/buku-dunas.pdf (accessed 24th April, 2014).

18. Dylst $P$, Vulto A, Simoens S. Demand-side policies to encourage the use of generic medicines: an overview. Expert Rev Pharmacoecon Outcomes Res. 2013;13(1):59-72. doi: 10.1586/erp.12.83

19. Alrasheedy AA, Hassali MA, Stewart K, Kong DC, Aljadhey H, Mohamed Ibrahim M, Al-Tamimi SK. Patient knowledge, perceptions, and acceptance of generic medicines: a comprehensive review of the current literature. Patient Intell. 2014;6:1-29. doi: 10.2147/PI.S46737

20. Hassali MA, Kong DCM, Stewart K. Generic medicines: perceptions of consumers in Melbourne, Australia. Int J Pharm Pract. 2005;13(4):257-264. doi: 10.1211/ijpp.13.4.0004

21. Babar ZUD, Stewart J, Reddy S, Alzaher W, Vareed P, Yacoub N, Dhroptee B, Rew A. An evaluation of consumers' knowledge, perceptions and attitudes regarding generic medicines in Auckland. Pharm World Sci. 2010;32(4):440-448 doi: 10.1007/s11096-010-9402-0

22. Hassali MAA, Shafie AA, Jamshed S, Ibrahim MIM, Awaisu A. Consumers' views on generic medicines: a review of the literature. Int J Pharm Pract. 2009;17(2):79-88.

23. Thomas R, Vitry A. Consumers' perception of generic medicines in community pharmacies in Malaysia. South Med Rev. 2009;2(2):20-23.

24. Al-Gedadi NA, Hassali MA, Shafie AA. A pilot survey on perceptions and knowledge of generic medicines among consumers in Penang, Malaysia. Pharm Pract (Granada). 2008;6(2):93-97.

25. Wong ZY, Hassali MA, Alrasheedy AA, Saleem F, Yahaya AHM, Aljadhey H. Malaysian generic pharmaceutical industries: Perspectives from healthcare stakeholders. J Pharm Health Serv Res. 2014. (In Press). doi: 10.1111/jphs.12072

26. Kumar R, Hassali MAA, Kaur N, Muhamad Ali SK Abdul Kader. Perceptions of physicians from private medical centres in Malaysia about generic medicine usage: a qualitative study. GaBI J. 2014;3(2):63-70.

27. Pharmaceutical Association of Malaysia. Government hospitals. 2014. Available from: http://www.phama.org.my/index.cfm?\&menuid=34 (accessed 14th January, 2014)

28. Israel GD. Determining sample size. University of Florida Cooperative Extension Service, Institute of Food and Agriculture Sciences, EDIS; 1992.

29. Figueiras MJ, Alves NC, Marcelino D, Cortes MA, Weinman J, Horne R. Assessing lay beliefs about generic medicines: development of the Generic Medicines Scale. Psychol Health Med. 2009;14(3):311-321. doi: 10.1080/13548500802613043

30. Wong ZY, Hassali MA, Saleem F, Yahaya AHM. Translation and validation of the Malaysian version of Generic Medicine Scale (GMS). J Med Market. 2014;14(1)32-40. doi: 10.1177/1745790414540928

31. Pallant J. SPSS survival manual: a step by step guide to data analysis using SPSS for Windows (Version 12). Australia: Allen \& Unwin; 2005.

32. Field A. Discovering statistics using SPSS. Thousand Oaks, CA: Sage; 2009.

33. Jaafar S, Noh KM, Muttalib KA, Othman NH, Healy J, Maskon K, Abdullah AR, Zainuddin J, Bakar AA, Rahman SSA, Ismail F, Yuen CY, Baba N, Said ZM. Malaysia health system review. Health Syst Transit. 2013; 3(1):103.

34. Alrasheedy AA, Hassali MA, Aljadhey H, Ibrahim MIM, Al-Tamimi SK. Is there a need for a formulary of clinically interchangeable medicines to guide generic substitution in Saudi Arabia? J Young Pharm. 2013;5(2):73-5. doi: 10.1016/j.jyp.2013.06.006

35. Gossell-Williams M, Harriott K. Generic substitution in Jamaica: challenges to improving effectiveness. WHO Drug Information. 2007;21(4):294-299.

36. Al Ameri MN, Whittaker C, Tucker A, Yaqoob M, Johnston A. A survey to determine the views of renal transplant patients on generic substitution in the UK. Transpl Int. 2011;24(8):770-779. doi: 10.1111/j.1432-2277.2011.01268.x 
37. Kobayashi E, Karigome H, Sakurada T, Satoh N, Ueda S. Patients' attitudes towards generic drug substitution in Japan. Health Policy. 2011;99(1):60-65. doi: 10.1016/j.healthpol.2010.07.006

38. Shrank WH, Cadarette SM, Cox E, Fischer MA, Mehta J, Brookhart AM, Avorn J, Choudhry NK. Is there a relationship between patient beliefs or communication about generic drugs and medication utilization? Med Care. 2009;47(3):319325. doi: 10.1097/MLR.0b013e31818af850

39. Hassali MA, Awaisu A, Shafie AA, Saeed MS. Professional training and roles of community pharmacists in Malaysia: views from general medical practitioners. Malays Fam Physician 2009;4(2-3):71-76.

40. Pharmaceutical Services Division. Poison Act 1952. 2013. Available from: http://www.pharmacy.gov.my/v2/sites/default/files/document-upload/poisons-act-1952-act-366.pdf (accessed 23th October, 2013).

41. Himmel W, Simmenroth-Nayda A, Niebling W, Ledig T, Jansen R-D, Kochen M, Gleiter C, Hummers-Pradier E. What do primary care patients think about generic drugs? Int J Clin Pharmacol Ther. 2005;43(10):472-479.

42. Losifescu A, Halm EA, McGinn T, Siu AL, Federman AD. Beliefs about generic drugs among elderly adults in hospitalbased primary care practices. Patient Educ Couns. 2008;73(2):377-83. doi: 10.1016/j.pec.2008.07.012

43. Håkonsen $\mathrm{H}$, Toverud EL. A review of patient perspectives on generics substitution: what are the challenges for optimal drug use. GaBi J. 2012;1(1):28-32.

44. Federman AD, Halm EA, Siu AL. Use of generic cardiovascular medications by elderly Medicare beneficiaries receiving generalist or cardiologist care. Med Care. 2007;45(2):109-115.

45. Heikkilä R, Mäntyselkä P, Hartikainen-Herranen K, Ahonen R. Customers' and physicians' opinions of and experiences with generic substitution during the first year in Finland. Health Policy. 2007;82(3):366-374.

46. Quintal C, Mendes P. Underuse of generic medicine in Portugal: an empirical study on the perceptions and attitudes of patients and pharmacists. Health Policy. 2012;104(1):61-8. doi: 10.1016/j.healthpol.2011.10.001

47. Shrank WH, Cox ER, Fischer MA, Mehta J, Choudhry NK. Patients' Perceptions of Generic Medications. Health Aff (Millwood). 2009;28(2):546-56. doi: 10.1377/hlthaff.28.2.546

48. Sewell K, Andreae S, Luke E, Safford MM. Perceptions of and barriers to use of generic medications in a rural African American population, Alabama. Prev Chronic Dis. 2012;9:E142. doi: 10.5888/pcd9.120010

49. Ngo SN, Stupans I, McKinnon RA. Generic substitution in the treatment of epilepsy: Patient attitudes and perceptions. Epilepsy Behav. 2013;26(1):64-66. doi: 10.1016/j.yebeh.2012.10.032.

50. Al Ameri M, Mohamed W, Makramalla E, Shalhoub B, Tucker A, Johnston A. Renal patients' views on generic prescribing and substitution: example from the United Arab Emirates. East Mediterr Health J. 2013;19(4):373-381.

51. Sicras-Mainar A, Navarro-Artieda R. Physicians' and patients' opinions on the use of generic drugs. J Pharmacol Pharmacother. 2012;3(3):268-270. doi: 10.4103/0976-500X.99438

52. Lebanova H, Manolov D, Getov I. Patient's attitude about generics-Bulgarian perspective. Marmara Pharm J. 2012;16:36-40.

53. Figueiras MJ, Marcelino D, Cortes MA. People's views on the level of agreement of generic medicines for different illnesses. Pharm World Sci. 2008;30(5):590-594. doi: 10.1007/s11096-008-9247-y

54. Gaither CA, Kirking DM, Ascione FJ, Welage LS. Consumers' views on generic medications. J Am Pharm Assoc. 2001;41(5):729-736.

55. Kaplan WA, Ritz LS, Vitello M, Wirtz VJ. Policies to promote use of generic medicines in low and middle income countries: a review of published literature, 2000-2010. Health Policy. 2012;106(3):211-224. doi: 10.1016/j.healthpol.2012.04.015

56. Hassali MA, Yuen KH, Ibrahim MIM, Wong JW, Ng BH, San Ho DS. Malaysian pharmaceutical industry: opportunities and challenges. J Generic Med. 2009;6(3):246-252.

57. Ministry of Health Malaysia. Malaysian guidelines for the conduct of bioavailability and bioequivalence studies. 2000. Available from: http://portal.bpfk.gov.my/index.cfm?\&menuid=67\&parentid=82\&highlightid=78 (accessed 8th November, 2012).

58. Sharrad AK, Hassali MA. Consumer perception on generic medicines in Basrah, Iraq: Preliminary findings from a qualitative study. Res Social Adm Pharm. 2011;7(1):108-112. doi: 10.1016/j.sapharm.2009.12.003

59. Toverud EL, Røise AK, Hogstad G, Wabø I. Norwegian patients on generic antihypertensive drugs: a qualitative study of their own experiences. Eur J Clin Pharmacol. 2011;67(1):33-38. doi: 10.1007/s00228-010-0935-x

60. Simoens S, Coster SD. Sustaining generic medicines markets in Europe. J Generic Med. 2006;3(4):257-268. doi: 10.1057/palgrave.jgm.4940128 